ISSN 1507-3866

e-ISSN 2449-9994

\author{
Alicja Grześkowiak \\ Uniwersytet Ekonomiczny we Wrocławiu \\ e-mail: alicja.grzeskowiak@ue.wroc.pl
}

\title{
BADANIE OPINII POLSKICH PRACODAWCÓW O UMIEJETNOŚCIACH ABSOLWENTÓW SZKÓŁ WYŻSZYCH Z WYKORZYSTANIEM TECHNIK WIZUALIZACYJNYCH
}

\section{EVALUATION OF POLISH EMPLOYERS' OPINIONS ABOUT THE COMPETENCES OF HIGHER EDUCATION GRADUATES WITH THE USE OF VISUALIZATION TECHNIQUES}

DOI: 10.15611/ekt.2015.2.05

Streszczenie: Głównym celem artykułu jest zaprezentowanie prawidłowości dotyczących postrzegania przez polskich pracodawców kompetencji absolwentów szkół wyższych w kontekście potrzeb rynku pracy. Analizy przeprowadzono na podstawie danych sondażowych zgromadzonych i udostępnionych w ramach badania Flash Eurobarometer. Ponieważ zbiór rozpatrywanych zmiennych zawiera wyłącznie dane niemetryczne, w celu identyfikacji prawidłowości zastosowano wybrane techniki wizualizacyjne (wykresy fluktuacyjne, wielokrotne względne wykresy słupkowe). Przeprowadzono również badanie współwystępowania umiejętności za pomocą analizy głównych składowych dla zmiennych niemetrycznych i przedstawiono graficznie jej rezultaty. Otrzymane wyniki wskazują, że polscy pracodawcy oceniają umiejętności absolwentów raczej pozytywnie, choć dostrzegają także luki kompetencyjne w różnych obszarach.

Słowa kluczowe: umiejętności, absolwenci szkół wyższych, wizualizacja danych niemetrycznych.

Summary: The main objective of this article is to present the patterns of Polish employers' perception of competences of higher education graduates in the context of labor market needs. The analyzes are carried out on the basis of survey data collected and made available by the Flash Eurobarometer. Since the set of variables under consideration contains only non-metric data, some selected visualization techniques (fluctuation diagrams, relative multiple barcharts) are applied to identify the regularities. Categorical principal components analysis and its graphical representation are used to analyze the interdependences among the considered competences. The results indicate that Polish employers evaluate the skills of the graduates rather positively, but they also recognize the competency gaps in various areas.

Keywords: competences, graduates of universities, non-metric data visualization. 


\section{Wstęp}

Przemiany, które zaszły w Polsce po 1989 roku, dotyczyły wielu sfer życia, w tym edukacji na poziomie wyższym. Współczynnik skolaryzacji netto w szkolnictwie wyższym wzrósł z poziomu 9,6\% w 1990 roku do 40,6\% w 2011 roku [Ministerstwo Nauki i Szkolnictwa Wyższego 2013, s. 5]. Zgodnie z Ustawą Prawo o szkolnictwie wyższym jednym z zasadniczych celów uczelni jest „kształcenie studentów w celu zdobywania i uzupełniania wiedzy oraz umiejętności niezbędnych w pracy zawodowej" [Ustawa z 27 lipca 2005, art. 13]. Dane statystyczne wskazują, że osoby z wykształceniem wyższym mają większe szanse na znalezienie pracy od pozostałych [Ministerstwo Nauki i Szkolnictwa Wyższego 2013, s. 56], co sugeruje, że cel jest $\mathrm{w}$ pewnym stopniu osiągany. $\mathrm{Z}$ drugiej strony akcentuje się problem niedostosowania umiejętności absolwentów uczelni do potrzeb rynku pracy, co z kolei może przyczyniać się do bezrobocia wśród młodych ludzi kończących edukację formalną.

Artykuł porusza problematykę oceny umiejętności absolwentów szkół wyższych w Polsce w kontekście ich przydatności na rynku pracy. Analizy wykonano na podstawie danych zgromadzonych $w$ trakcie badania pracodawców przeprowadzonego przez Eurobarometer.

Główny cel opracowania ma charakter poznawczy, polegający na wykryciu prawidłowości w zakresie postrzegania przez pracodawców kompetencji absolwentów. Sformułowano trzy hipotezy badawcze:

- ocena przygotowania absolwentów szkół wyższych może być różna w firmach/ organizacjach o różnych charakterystykach; na sposób oceny mogą mieć wpływ: wielkość firmy, rodzaj działalności, struktura właścicielska lub kombinacje tych elementów;

- istnieje niedopasowanie oczekiwań pracodawców i faktycznych umiejętności, którymi dysponują absolwenci uczelni;

- oceny umiejętności mogą tworzyć pewne wzorce, które można zidentyfikować, stosując stosowne techniki redukcji wielowymiarowości.

Rozpatrywany zestaw danych pochodzących z badania sondażowego składa się wyłącznie ze zmiennych, których pomiar został dokonany na słabych skalach pomiarowych - nominalnej i porządkowej. Charakter posiadanych danych warunkuje wykorzystanie stosownych metod analitycznych i z tego względu celem pobocznym artykułu, o charakterze metodycznym, jest wskazanie i aplikacja wybranych technik wizualizacji danych, które są raczej rzadko stosowane w analizie danych społeczno-ekonomicznych, a mogą być pomocne w identyfikacji istniejących prawidłowości.

Istnieje grupa procedur badania niemetrycznych danych wielowymiarowych przyjmujących za punkt wyjścia tabele kontyngencji, np. analiza korespondencji czy analiza log-liniowa. $\mathrm{Z}$ drugiej strony do badania tabel wielodzielczych coraz częściej stosuje się różne techniki wizualizacji, które zyskują na znaczeniu w miarę rozbudowy stosownego oprogramowania. Liczne metody graficznej prezentacji danych zawierają różne pakiety programu $\mathrm{R}$, których niewątpliwymi zaletami są 
powszechna dostępność i brak opłat licencyjnych. Przegląd wielu metod wizualizacji dla danych pochodzących ze słabych skal pomiarowych można znaleźć w pracy [Friendly 2000]. W niniejszej pracy wykorzystano dwa rodzaje prezentacji obrazujących relacje zachodzące w tabelach kontyngencji: po pierwsze, wykresy fluktuacyjne (fluctuation diagrams) [Hofmann 2000], po drugie, jedną z najnowszych propozycji w tym obszarze - wielokrotne względne wykresy słupkowe (relative multiple barchars) [Pilhoefer, Unwin 2013].

Analiza danych niemetrycznych z wykorzystaniem wymienionych technik wizualizacji ma jednak znaczące ograniczenie - prezentacja staje się nieczytelna lub wręcz niemożliwa w razie dysponowania dużą liczbą zmiennych. Alternatywnym postępowaniem w takiej sytuacji może być zastosowanie metod umożliwiających redukcję wielowymiarowości. Jeżeli celem jest zbadanie struktury relacji pomiędzy zmiennymi, można posłużyć się analizą głównych składowych dla zmiennych niemetrycznych (categorical principal components analysis - CATPCA). Rezultaty analizy można także zaprezentować graficznie, przedstawiając strukturę czynnikową. W artykule przedstawiono właśnie takie zastosowanie metody CATPCA, umożliwiające przejrzyste ujęcie relacji pomiędzy rozpatrywanymi zmiennymi zmierzonymi na skali porządkowej.

\section{Charakterystyka materiału badawczego}

Do analizy wykorzystano dane zgromadzone w trakcie badania Flash 304 Eurobarometer Survey „Employers' Perception of Graduate Employability”. Sondaż przeprowadzono w 2010 roku we wszystkich krajach Unii Europejskiej oraz w Norwegii, Turcji, Chorwacji i na Islandii. Badaniem opinii za pomocą wywiadu telefonicznego objęto firmy zatrudniające co najmniej pięćdziesięciu pracowników, działające w różnych sektorach gospodarki [European Commission 2010, s. 4]. Prezentowana praca koncentruje się na sytuacji w Polsce, co oznacza wykorzystanie jedynie części dostępnych danych. W szczególności analizie poddano odpowiedzi na następujące pytania [ZA5447 Flash Eurobarometer...(2014), s. 4-5]:

1. Pytanie o charakterze ogólnym: „W jakim stopniu zgadza się Pan(i) lub nie zgadza się z następującym stwierdzeniem? Absolwenci studiów wyższych zrekrutowani w ciągu ostatnich od 3 do 5 lat mają umiejętności wymagane do tego, aby pracować w mojej firmie" (możliwe cztery odpowiedzi: zdecydowanie się nie zgadzam, nie zgadzam się, zgadzam się, zdecydowanie zgadzam się).

2. Pytania dotyczące poszczególnych umiejętności i kompetencji:

a) ważność z punktu widzenia organizacji „Proszę ocenić następujące umiejętności i kompetencje, w kontekście tego, jak ważne są one, kiedy w Pana(i) firmie

${ }^{1}$ European Commission (2011): Flash Eurobarometer 304 (Employers' Perception of Graduate Employability). The GALLUP Organization, Brussels. GESIS Data Archive, Cologne. ZA5447 Data file Version 1.0.0, doi: 10.4232/1.10241. 
rekrutuje się absolwentów szkół wyższych" (możliwe cztery odpowiedzi: w ogóle nie sa ważne, raczej nieważne, raczej ważne, bardzo ważne),

b) stopień spełnienia oczekiwań: „Czy może Pan(i) ocenić swoje zadowolenie z absolwentów szkół wyższych, których Pana(i) firma/organizacja zrekrutowała w ciągu ostatnich od 3 do 5 lat w zakresie następujących umiejętności i kompetencji" (możliwe cztery odpowiedzi: w ogóle nie jest zadowolony (a), raczej niezadowolony (a), raczej zadowolony (a), bardzo zadowolony (a)).

Lista ocenianych umiejętności i kompetencji była jednakowa dla obu pytań wymienionych w pkt. 2 i składała się z następujących elementów [ZA5447 Flash Eurobarometer..., s. 5]:

- „dobry z liczbami,

- umiejętności dobrego czytania,

- znajomość języków obcych,

- umiejętności komputerowe,

- umiejętności związane z konkretną branżą,

- umiejętności komunikacyjne,

- umiejętności analityczne i rozwiązywania problemów,

- zdolność do przystosowania się i działania w nowych sytuacjach,

- umiejętności podejmowania decyzji,

- umiejętności pracy w grupie,

- umiejętności planowania i organizacji”.

Drugą grupę danych tworzą elementy charakteryzujące firmy i organizacje:

- wielkość (średnie: 50-249 pracowników, duże: 250 i więcej pracowników); należy zwrócić uwagę, że podział stosowany w tym badaniu opiera się wyłącznie na kryterium liczby zatrudnionych i nie jest tożsamy z pojęciem małego i średniego przedsiębiorstwa według polskiego prawodawstwa uwzględniającego dodatkowo kryteria rocznego obrotu netto i sumy aktywów bilansu [Ustawa z 2 lipca 2004, art. 105-106];

- struktura właścicielska (publiczna, prywatna);

- rodzaj głównej działalności (ze względu na bardzo małe liczebności niektórych grup działalności zgodnych z klasyfikacją PKD 2007 dane zostały skategoryzowane w następujący sposób: przemysł i budownictwo, usługi).

W istniejącej bazie danych pierwotnych wystąpiły braki, które usunięto, otrzymując liczbę rekordów: $376 \mathrm{w}$ ramach badania wyłącznie zestawu umiejętności oraz 358 rekordów w ramach zestawienia obejmującego charakterystyki firm/organizacji. Różna liczba obserwacji wynika z faktu, że niektóre braki danych dotyczyły wyłącznie charakterystyk firm i pytania ogólnego, a nie szczegółowej listy kompetencji.

\section{Ogólna ocena umiejętności absolwentów a wyróżniki instytucji}

Wyniki sondażu wskazują, że ogólne zadowolenie z umiejętności prezentowanych przez absolwentów szkół wyższych jest raczej wysokie. $27 \%$ pracodawców zdecydo- 
wanie zgadza się, a 62\% - zgadza się ze stwierdzeniem, że zrekrutowani absolwenci mają odpowiednie umiejętności do pracy w firmie [European Commission 2010, s. 24]. Struktura odpowiedzi na to pytanie wykazuje zróżnicowanie w poszczególnych krajach, np. dla Polski charakterystyczne jest ostrożniejsze wyrażanie zadowolenia - dominującą odpowiedzią było sformułowanie „zgadzam się” (73\% odpowiedzi), podczas gdy ,zdecydowanie zgadzam się” wskazało tylko $13 \%$ respondentów [European Commision 2010, s. 24].

Zgodnie z postawioną hipotezą badawczą ocena absolwentów może różnić się w zależności od tego, do jakiej firmy/instytucji byli oni przyjęci. Przedmiotem zainteresowania jest więc kształtowanie się jednej zmiennej (oceny absolwentów), którą można określić mianem objaśnianej, w odniesieniu do zestawu charakterystyk firm/instytucji (wielkość, struktura własnościowa, rodzaj działalności), które można określić objaśniającymi. W celu prześledzenia rozkładów odpowiedzi jednej zmiennej w relacji do zbioru zmiennych opisujących zastosowano wizualizację danych niemetrycznych zaproponowaną przez Pilhoefera i Unwina [2013] i polegającą na prezentacji wielokrotnych względnych wykresów słupkowych, co przez autorów określane jest skrótem rmb (od pierwszych liter nazwy angielskiej relative multiple barcharts). Idea wizualizacji zasadza się na wykorzystaniu dwóch zasadniczych elementów: zaobserwowanych liczebności kombinacji zmiennych objaśniających ${ }^{2} n_{+j k}$ oraz warunkowych rozkładów zmiennej objaśnianej określonych przez prawdopodobieństwa $p_{i \mid j k}$, przy czym liczebności $n_{+j k}$ znajdują odzwierciedlenie w powierzchni słupków reprezentowanych horyzontalnie, a warunkowe prawdopodobieństwa $p_{i \mid j k}$ w ilustracji za pomocą kolumn zlokalizowanych w obrębie tych słupków [Pilhoefer, Unwin 2013]. Słupki (szare zacienienie) mają jednakową wysokość, a ich szerokość jest proporcjonalna do wielkości $n_{+j k} / \max \left(n_{+j k}\right)$ [Pilhoefer, Unwin 2013].

$\mathrm{Na}$ rysunku 1 przedstawiono ilustrację rozkładu zadowolenia z umiejętności absolwentów szkół wyższych w zależności od wielkości i struktury właścicielskiej instytucji. Układ słupków cieniowanych na szaro pozwala natychmiast zidentyfikować kombinację kategorii o największej liczebności. W wybranej próbie dominowały przedsiębiorstwa średnie znajdujące się w rękach prywatnych. Rozkłady odpowiedzi na pytanie będące przedmiotem zainteresowania zilustrowane za pomocą kolumn znajdują się w obrębie poszczególnych słupków. Dla wszystkich możliwych kombinacji kategorii zmiennych objaśniających występuje ta sama dominanta odpowiedzi (,zgadzam się” - kolor jasnoniebieski), co więcej - prawdopodobieństwo jej wystąpienia jest bardzo zbliżone we wszystkich przypadkach. Co ciekawe, w instytucjach publicznych nie znalazły się odpowiedzi skrajnie negatywne (,zdecydowanie nie zgadzam się" - kolor czerwony). Pojawiają się one natomiast w organizacjach prywatnych, choć ich znaczenie jest raczej marginalne. Z kolei największe praw-

${ }^{2}$ Przedstawiony zapis, użyty przez autorów propozycji, dotyczy przypadku trzech zmiennych, przy czym indeks $i$ odnosi się do zmiennej objaśnianej. Uogólnienie na większą liczbę zmiennych jest oczywiste. 
dopodobieństwo odpowiedzi z drugiego końca skali (,zdecydowanie zgadzam sięe” - kolor fioletowy) występuje w dużych instytucjach publicznych, których przedstawiciele oceniają umiejętności absolwentów najlepiej.

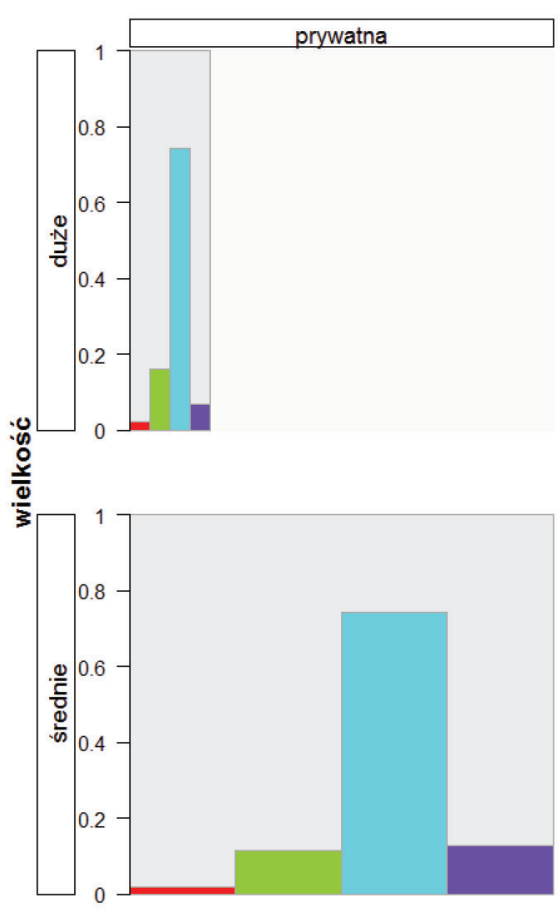

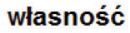
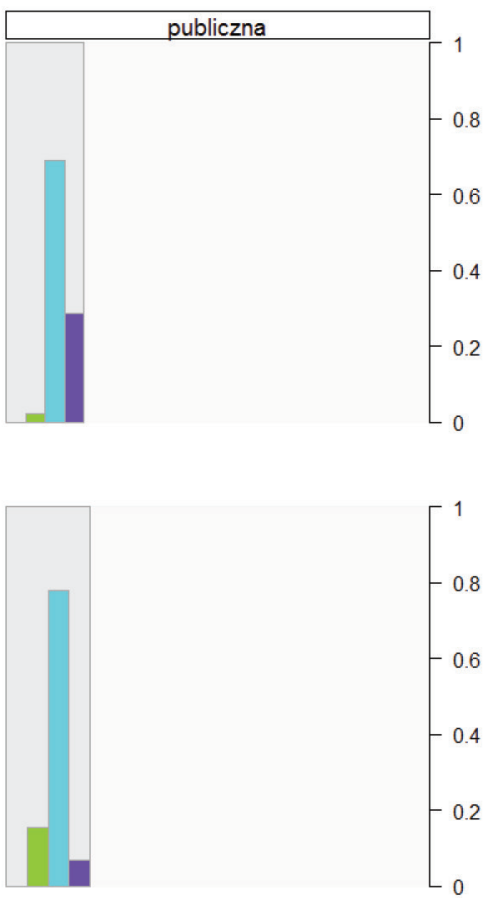

Rys. 1. Zadowolenie z umiejętności absolwentów w zależności od wielkości i struktury właścicielskiej firm/organizacji (kolor czerwony - zdecydowanie się nie zgadzam, kolor zielony nie zgadzam się, kolor niebieski - zgadzam sie, kolor fioletowy - zdecydowanie zgadzam się ze stwierdzeniem)

Źródło: opracowanie własne z wykorzystaniem programu R, na podstawie danych Flash Eurobarometer 304.

Zastosowanie wielokrotnych względnych wykresów słupkowych nie ogranicza się do sytuacji dwóch zmiennych objaśniających. W razie dysponowania większą ich liczbą możliwe jest uwzględnienie kolejnych podziałów w wizualizacji. Rysunek 2 zawiera graficzną reprezentację analizowanych danych po rozszerzeniu zbioru zmiennych objaśniających o rodzaj głównej działalności w podziale na przemysł i budownictwo oraz usługi.

Najliczniejszą kategorię respondentów stanowiły średnie firmy prywatne o głównym rodzaju działalności zlokalizowanym w obrębie przemysłu i budownictwa. Zwracają uwagę nieomalże ,puste” kombinacje kategorii - stanowione przez firmy i organizacje publiczne działające w zakresie przemysłu i budownictwa. Daje 


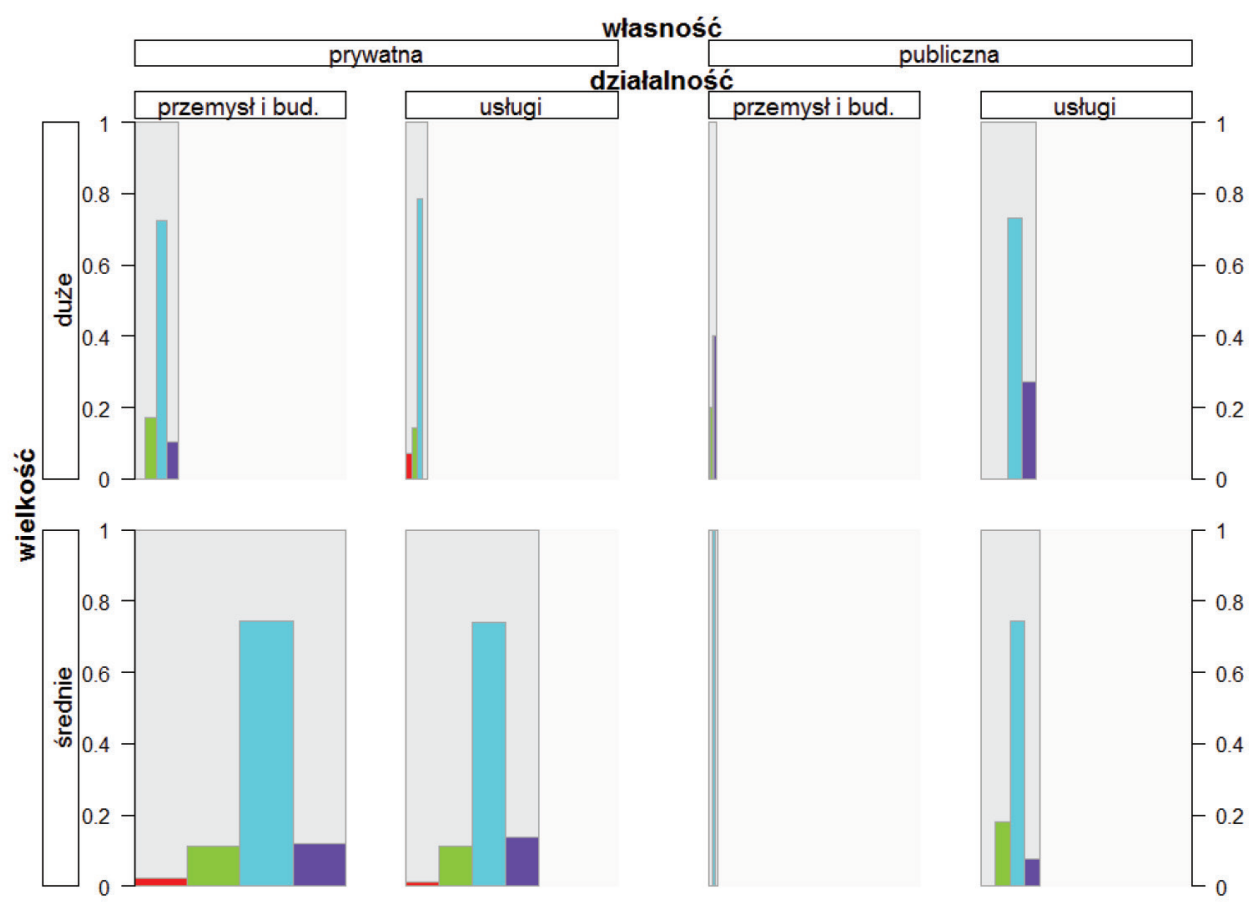

Rys. 2. Zadowolenie z umiejętności absolwentów w zależności od wielkości, struktury właścicielskiej oraz rodzaju głównej działalności firm/organizacji (kolor czerwony - zdecydowanie się nie zgadzam, kolor zielony - nie zgadzam się, kolor niebieski - zgadzam się, kolor fioletowy zdecydowanie zgadzam się)

Źródło: opracowanie własne z wykorzystaniem programu R, na podstawie danych Flash Eurobarometer 304.

to wskazówkę, że wyciąganie wniosków na ich podstawie jest nieuzasadnione. Wprowadzenie kolejnej zmiennej nie wpłynęło na kształtowanie się dominanty. Dla wszystkich kombinacji kategorii zmiennych objaśniających (odpowiednio licznych, by móc przeprowadzać interpretację) modalna to sformułowanie „zgadzam się", a prawdopodobieństwo wystąpienia tego stwierdzenia jest zbliżone we wszystkich przypadkach. Warto zauważyć, że rozkłady odpowiedzi uzyskane dla średnich firm/ organizacji prywatnych nie wykazują zróżnicowania ze względu na rodzaj działalności. Przedstawiciele średnich przedsiębiorstw trudniących się przemysłem i budownictwem oceniają umiejętności absolwentów bardzo podobnie jak przedstawiciele średnich przedsiębiorstw usługowych. Najwięcej skrajnie negatywnych odpowiedzi zostało udzielonych przez respondentów związanych z dużymi firmami prywatnymi działającymi $\mathrm{w}$ sferze usług. $\mathrm{Z}$ tą prawidłowością kontrastują opinie pochodzące $\mathrm{z}$ dużych firm/organizacji publicznych, w których prawdopodobieństwo podania skrajnie pozytywnych odpowiedzi jest najwyższe. 


\section{Ocena rozbieżności pomiędzy oczekiwaniami pracodawców a umiejętnościami absolwentów}

W badaniu percepcji zatrudniania absolwentów przez pracodawców w ramach Flash Eurobarometer uwzględniono jedenaście umiejętności, które zostały wymienione w punkcie 2 niniejszego opracowania. Pracodawcy opiniowali w skali czterostopniowej ważność poszczególnych kompetencji oraz stopień zadowolenia z absolwentów w zakresie tych samych kategorii, co stwarza możliwość porównania oczekiwań ze stanem faktycznym. W celu oceny przyjęto założenie, że jednakowe odpowiedzi dla pytań o ważność i ocenę dysponowania danym rodzajem kompetencji oznaczają zgodność pomiędzy oczekiwaniami pracodawców a stanem faktycznym. Z kolei wyższa ocena ważności niż stopnia zadowolenia z umiejętności absolwentów świadczy o niedoborze umiejętności, przy czym im większa różnica, tym dotkliwszy brak kompetencji. Przedstawione podejście jest oczywiście pewnym uproszczeniem, ale pozwala na identyfikację rozbieżności.

Ponieważ odpowiedzi na pytania o poszczególne kompetencje były udzielane na skali czterostopniowej, łączny rozkład liczebności reprezentowany jest w dwuwymiarowych tabelach kontyngencji, których wizualizację można przeprowadzić za pomocą wykresów fluktuacyjnych [Hofmann 2000]. Tego rodzaju prezentacja zawiera tyle samo pól, ile posiada reprezentowana tabela kontyngencji i są one rozmieszczone analogicznie do położenia komórek tabeli. Liczebności komórek są odzwierciedlane za pomocą powierzchni figur zlokalizowanych w poszczególnych polach. Tworzenie wizualizacji tego typu jest dostępne w programie $\mathrm{R} z$ użyciem kwadratów, prostokątów, kół, ośmioboków oraz rombów [Pilhoefer 2014]. Na rysunku 3 zaprezentowano przykładowe wykresy fluktuacyjne z zastosowaniem kwadratów i prostokątów. W dalszej części pracy użyto wariantu zawierającego kwadraty, których długość boków jest proporcjonalna do pierwiastka z liczebności $n_{j k}$.
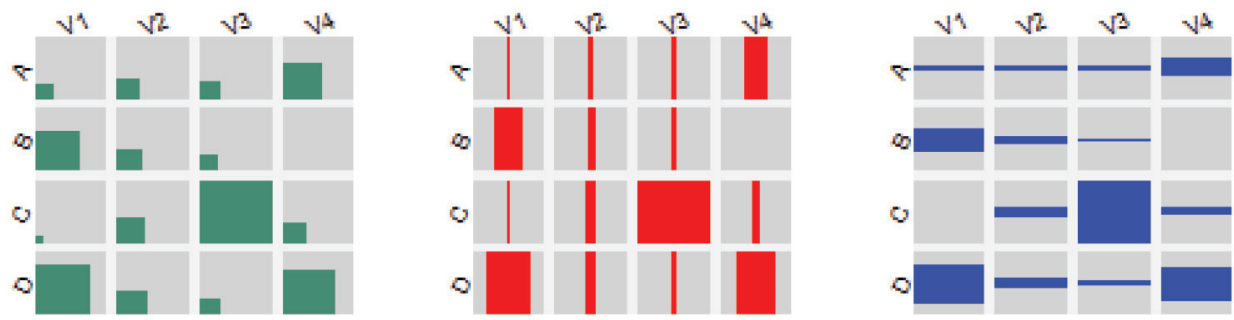

Rys. 3. Przykładowe wykresy fluktuacyjne dla tabeli $4 x 4$ (A-D - warianty jednej cechy, V1-V4 warianty drugiej cechy).

Źródło: opracowanie własne z wykorzystaniem programu R.

Na rysunku 4 przedstawiona jest wizualizacja tabel kontyngencji odzwierciedlających relacje pomiędzy oceną ważności poszczególnych umiejętności w skali 1-4 


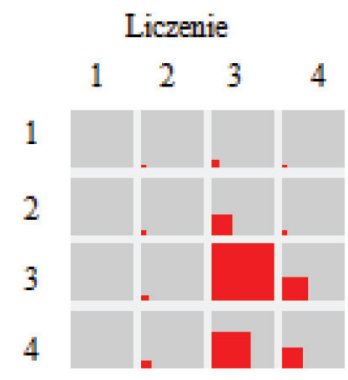

Znajomość branży

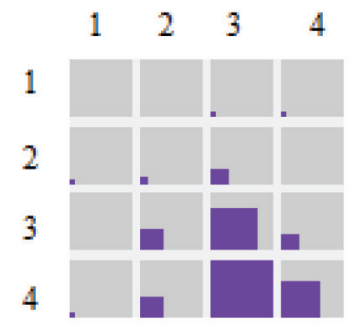

Umiejętności analityczne
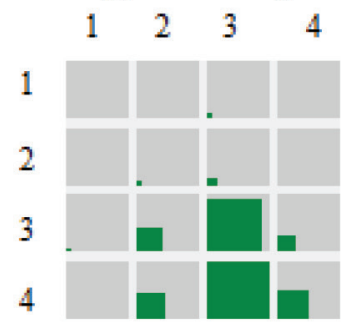

Czytaniepisanie

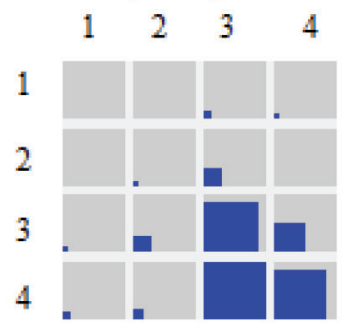

Obshuga komputera

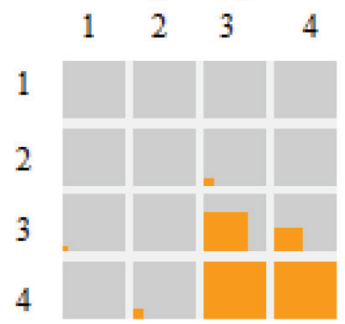

Adaptacyjność

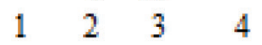

1

2

3

4
Jezyli obce

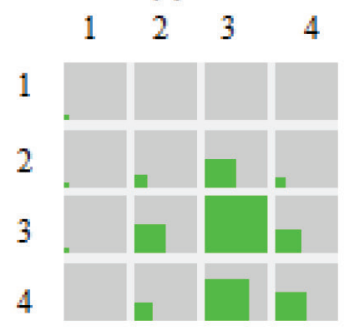

Komunikacja

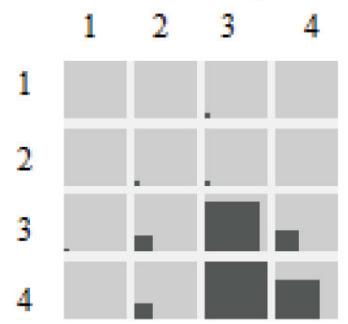

Podejmowanie decyzji

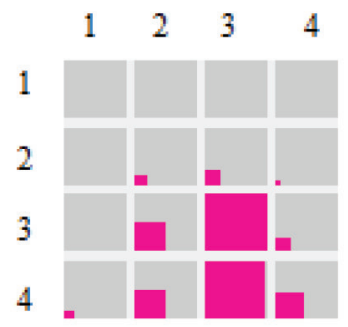

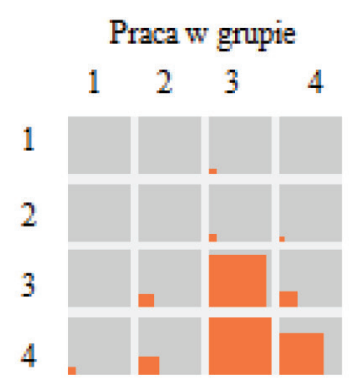

Planowanie

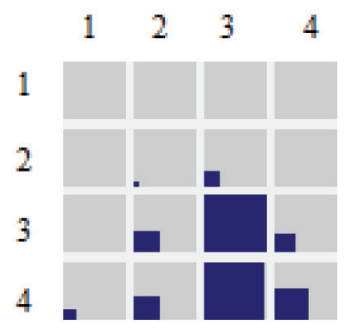

Rys. 4. Wizualizacja tabel kontyngencji ujmujących ocenę ważności umiejętności w skali 1-4 (wiersze) oraz stopnia zadowolenia z umiejętności posiadanych przez absolwentów w skali 1-4 (kolumny)

Źródło: opracowanie własne z wykorzystaniem programu R, na podstawie danych Flash Eurobarometer 304. 
(wiersze) a stopniem zadowolenia z umiejętności posiadanych przez absolwentów także w skali 1-4 (kolumny). Graficzne ujęcie tabel pozwala wskazać podstawowe prawidłowości:

- respondenci bardzo rzadko udzielali odpowiedzi skrajnie negatywnych (,1”);

- więcej odpowiedzi negatywnych (,2") wystąpiło w odniesieniu do oceny absolwentów niż w percepcji ważności umiejętności;

- należy podkreślić relatywnie duże liczebności na głównej przekątnej dla kombinacji odpowiedzi „3” i ,3” oraz „4” i „4”, czyli stosunkowo dużą zbieżność w ocenach;

- dla każdej umiejętności liczebność komórek pod główną przekątną zdecydowanie przewyższa liczebność nad główną przekątną, co wskazuje, że istniejące rozbieżności dotyczą niedoboru umiejętności;

- najczęstszym symptomem niedoboru jest kombinacja kategorii „,3” (ocena danej umiejętności absolwenta) i „4” (postrzeganie ważności danej umiejętności); mimo istniejącego niedopasowania taki zestaw opinii wydaje się dosyć optymistyczny - nie neguje umiejętności absolwentów, ale wskazuje, że potrzebne jest ich dalsze doskonalenie;

- istnieją kompetencje, dla których najwyższej ocenie ważności („4”) stosunkowo częściej towarzyszą negatywne opinie o absolwentach (,,1” oraz „2”), np. znajomość branży, umiejętności analityczne, umiejętność podejmowania decyzji, praca $\mathrm{w}$ grupie, planowanie i organizacja; w tych przypadkach deficyt umiejętności stanowi większe wyzwanie niż w pozostałych.

Do zweryfikowania hipotezy o symetrii kwadratowej tablicy kontyngencji o wymiarach $k \times k$ można wykorzystać statystykę [Everitt 1992, s. 115]:

$$
\chi^{2}=\sum_{i<j}\left(n_{i j}-n_{j i}\right)^{2} /\left(n_{i j}+n_{j i}\right)
$$

która w razie prawdziwości hipotezy zerowej $H_{0}: p_{i j}=p_{j i}$ dla $(i \neq j)$ ma rozkład $\chi^{2}$ z $0,5 k(k-1)$ stopni swobody [Everitt 1992, s. 114-115]. W tabeli 1 zestawiono wartości statystyki $\chi^{2}$ dla tablic odpowiadających poszczególnym umiejętnościom. Wszystkie wartości statystyki testowej prowadzą do odrzucenia hipotezy zerowej i potwierdzają intuicyjny wniosek wyciągnięty na podstawie wizualizacji przedstawionych na rys. 4 , ale dodatkowym atutem zastosowania statystyki $\chi^{2}$ jest możliwość porównania stopnia asymetrii tabel kontyngencji.

Najwyższe wartości miary $\chi^{2}$ wystąpiły w ramach opinii na temat umiejętności analitycznych. Znaczny stopień asymetrii odnotowano także dla umiejętności podejmowania decyzji, znajomości branży, umiejętności pracy w grupie, umiejętności organizacyjnych i komunikacyjnych. Użyta statystyka $\chi^{2}$ nie wskazuje „kierunku” asymetrii, w jego ocenie mogą być pomocne wykresy fluktuacyjne (rys. 4), które uwidaczniają, że brak symetrii wynika ze znacznego niedoboru kompetencji. Z kolei asymetria najsłabiej manifestuje się w odniesieniu do języków obcych. Stosunkowo 
Tabela 1. Wartości statystyki $\chi^{2}$ dla tabel kontyngencji reprezentujących poszczególne umiejętności

\begin{tabular}{|l|c|}
\hline \multicolumn{1}{|c|}{ Umiejętność } & Statystyka $\chi^{2}$ \\
\hline Liczenie & 33,37 \\
\hline Czytanie/pisanie & 57,75 \\
\hline Języki obce & 28,64 \\
\hline Znajomość branży & 133,99 \\
\hline Obsługa komputera & 80,01 \\
\hline Komunikacja & 107,21 \\
\hline Umiejętności analityczne & 155,53 \\
\hline Adaptacyjność & 69,88 \\
\hline Umiejętność podejmowania decyzji & 142,26 \\
\hline Praca w grupie & 121,95 \\
\hline Planowanie i organizacja & 116,91 \\
\hline
\end{tabular}

Źródło: obliczenia własne na podstawie danych Flash Eurobarometer 304.

niskie wartości statystyki $\chi^{2}$ dotyczą także takich kompetencji, jak liczenie oraz czytanie i pisanie.

\section{Współwystępowanie umiejętności absolwentów w ocenie pracodawców}

Analiza przeprowadzona w poprzednim punkcie traktowała każdą z rozpatrywanych umiejętności osobno. W realiach życiowych kompetencje pracowników nie funkcjonują oddzielnie, dana osoba najczęściej dysponuje całym ich zasobem, choć na różnych poziomach. Łączne badanie kompetencji musi więc zasadzać się na metodach analizy danych wielowymiarowych. W celu przedstawienia struktury relacji pomiędzy ocenami umiejętności absolwentów uczelni zastosowano analizę głównych składowych dla zmiennych niemetrycznych, której rezultaty można syntetycznie przedstawić graficznie.

Idea metody (zob. [De Leeuw 2006; Meulman, van der Kooij, Heiser 2004]) zasadza się na przekształcaniu kategorii zmiennych ze słabych skal pomiarowych w wartości numeryczne (tzw. kwantyfikacja lub skalowanie optymalne), co pozwala na przeprowadzenie analizy głównych składowych w jej klasycznym rozumieniu. Procedura jest oprogramowana w module CATPCA w SPSS Categories, który wykorzystuje iteracyjny algorytm osiągający rozwiązanie optymalne dla konkretnego zbioru zmiennych poprzez naprzemienne wykonywanie kwantyfikacji i standardowej analizy głównych składowych [Meulman, Heiser 2001].

Zastosowanie algorytmu CATPCA dla zbioru danych uwzględniającego oceny zadowolenia ze wszystkich jedenastu umiejętności pozwoliło wyodrębnić dwie główne 
składowe. Relacje pomiędzy poszczególnymi zmiennymi można prześledzić, stosując wykres struktury czynnikowej (rys. 5). Kluczowe dla interpretacji jest położenie wektorów względem siebie - im bliższe, tym korelacja pomiędzy zmiennymi jest wyższa, brakowi korelacji towarzyszy prostopadłość wektorów, a korelacji ujemnej położenie w przeciwnych ,„połówkach” układu współrzędnych [Stanisz 2007, s. 196].

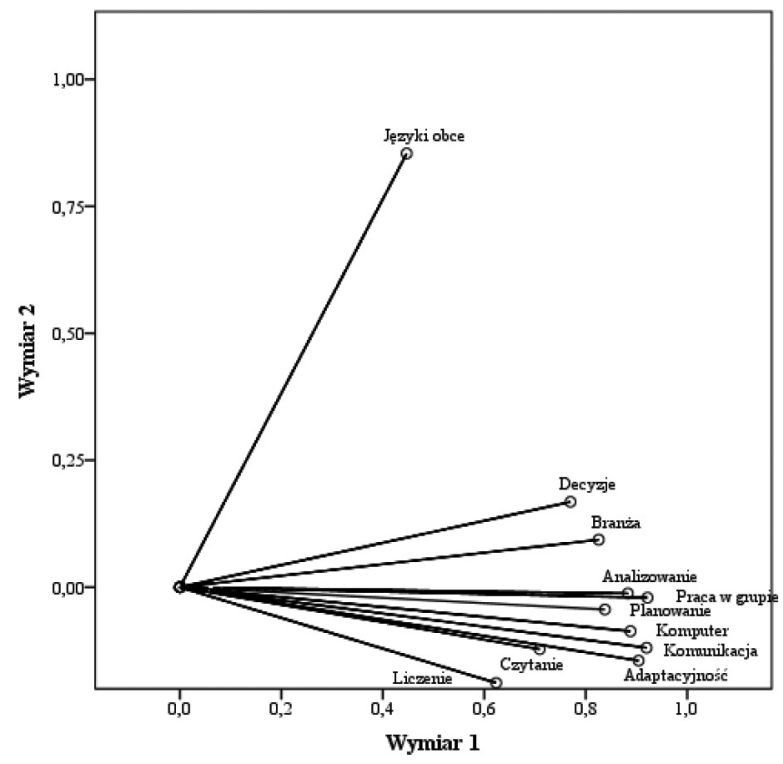

Rys. 5. Współrzędne czynnikowe otrzymane w procedurze CatPCA dla zmiennych reprezentujących zadowolenie $\mathrm{z}$ umiejętności absolwentów

Źródło: opracowanie własne z wykorzystaniem programu SPSS (PS IMAGO), na podstawie danych Flash Eurobarometer 304.

Układ wektorów na rys. 5 wskazuje, że respondenci dosyć podobnie oceniali umiejętności absolwentów. Wyjątek stanowi znajomość języków obcych, która jest słabo skorelowana lub nieskorelowana z pozostałymi kompetencjami. Nieco odmiennie od innych były też oceniane znajomość branży, umiejętność podejmowania decyzji i wykonywania obliczeń. Pozostałe kompetencje tworzą w zasadzie jeden zestaw.

\section{Zakończenie}

Polscy pracodawcy raczej dobrze oceniają umiejętności absolwentów, niemniej jednak w każdym z opiniowanych obszarów istnieją luki kompetencyjne. Występowanie niedoboru kompetencji jest stwierdzeniem zbieżnym z rezultatami opisanymi w pracy [SGH i in. 2012]. Odpowiedzi respondentów sondażu Eurobarometer wska- 
zują, że największe deficyty umiejętności dotyczą zdolności do podejmowania decyzji, znajomości branży, umiejętności pracy w grupie, umiejętności organizacyjnych i komunikacyjnych.

Ankietowani z organizacji publicznych, zwłaszcza dużych, częściej lepiej oceniali umiejętności absolwentów szkół wyższych niż przedstawiciele firm/organizacji prywatnych.

Rezultaty analizy głównych składowych skłaniają do odrzucenia hipotezy o występowaniu kilku grup kompetencji o podobnym postrzeganiu przez pracodawców. Jedynym elementem nieskorelowanym z pozostałymi jest znajomość języków obcych, natomiast dla pozostałych umiejętności odnotowano silną zależność pomiędzy opiniami, co pozwala przypuszczać, że wysokiej ocenie danej kompetencji towarzyszą zazwyczaj wysokie oceny dla pozostałych.

Zastosowanie technik wizualizacyjnych adekwatnych dla zmiennych niemetrycznych może być szczególnie przydatne w analizie danych sondażowych, umożliwiając wgląd w rozkłady i strukturę odpowiedzi.

Badanie Eurobarometer było prowadzone w 31 krajach. Na zakończenie rozważań warto przyjrzeć się ocenie umiejętności absolwentów w Polsce na tle innych państw. Na rysunku 6 zestawiono odsetki odpowiedzi raczej zadowolony oraz bardzo zadowolony (odpowiednio dla Polski oraz całej próby) udzielonych na pytanie o stopień zadowolenia z umiejętności i kompetencji absolwentów szkół wyższych zrekrutowanych w ciągu ostatnich trzech do pięciu lat.

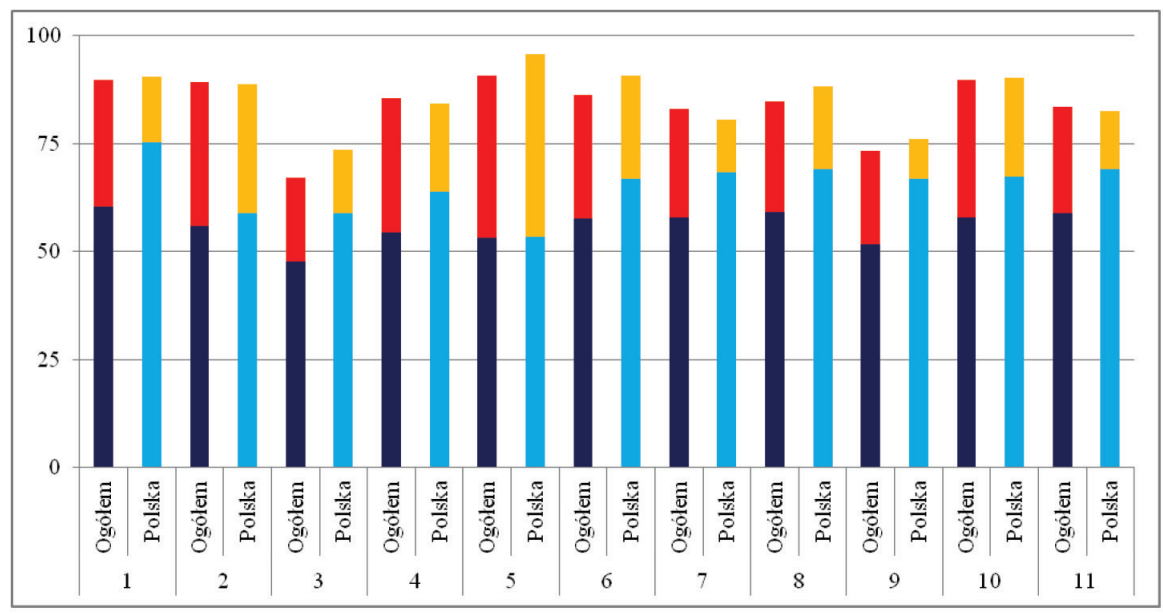

Rys. 6. Odsetek respondentów raczej zadowolonych (kolor granatowy dla ogółu oraz kolor niebieski dla Polski) oraz bardzo zadowolonych (kolor czerwony dla ogółu oraz kolor żółty dla Polski) z umiejętności i kompetencji absolwentów szkół wyższych (1 - liczenie, 2 - czytanie/pisanie, 3 - języki obce, 4 - znajomość branży, 5 - obsługa komputera, 6 - komunikacja, 7 - umiejętności analityczne, 8 - adaptacyjność, 9 - podejmowanie decyzji, 10 - praca w grupie, 11 - planowanie)

Źródło: opracowanie własne na podstawie [European Commission 2010]. 
Pracodawcy w Europie korzystnie oceniali kompetencje i umiejętności absolwentów uczelni. Odsetek opinii pozytywnych odnotowanych w Polsce był zbliżony do wartości obliczonych dla całej próby. Warto jednak zauważyć, że dla większości kategorii wśród polskich pracodawców zdecydowanie rzadziej pojawiała się ocena najwyższa bardzo zadowolony, a przeważała raczej zadowolony, co wskazuje na słabsze postrzeganie kompetencji osób rozpoczynających pracę po studiach w Polsce niż w zestawieniu ogólnoeuropejskim.

\section{Literatura}

De Leeuw J., 2006, Nonlinear Principal Component Analysis and Related Techniques, [w:] Greenacre M., Blasius J. (red.), Multiple Correspondence Analysis and Related Methods, Chapman \& Hall/ CRC, Boca Raton.

European Commission, 2010, Employers' perception of graduate employability. Analytical report, http://ec.europa.eu/public_opinion/flash/fl_304_en.pdf (25.09.2014).

Everitt B.S., 1992, The Analysis of Contingency Tables, Springer-Science+Business Media, B.V., New York.

Friendly M., 2000, Visualizing Categorical Data, SAS Institute Inc, Cary NC.

Hofmann H., 2000, Exploring categorical data: interactive mosaic plots, Metrika, 51(1), s. 11-26.

Meulman J. J., Heiser J., 2001, SPSS Categories 11.0, SPSS Inc., Chicago.

Meulman J.J., van der Kooij A.J., Heiser W.J., 2004, Principal Components Analysis with Nonlinear Optimal Scaling Transformations for Ordinal and Nominal Data, [w:] Kaplan D. (red.), The Sage Handbook of Quantitative Methodology for the Social Sciences, Sage Publications, Thousand Oaks.

Ministerstwo Nauki i Szkolnictwa Wyższego, 2013, Szkolnictwo wyższe w Polsce, http://www.nauka. gov.pl/g2/oryginal/2013_07/0695136d37bd577c8ab03acc5c59a1f6.pdf (08.10.2014).

Pilhoefer A., 2014, Extracat: Categorical Data Analysis and Visualization, R package ver. 1.7-0, http:// cran.r-project.org/web/packages/extracat/index.html (28.09.2014).

Pilhoefer A., Unwin A., 2013, New Approaches in Visualization of Categorical Data: R Package extracat, Journal of Statistical Software, vol. 53, issue 7.

SGH, Ernst\&Young, Amerykańska Izba Handlu w Polsce, 2012, Kompetencje i kwalifikacje poszukiwane przez pracodawców wśród absolwentów szkół wyższych wchodzacych na rynek pracy, Warszawa, http:// firma.sgh.waw.pl/pl/Documents/RKPK_raport_2012.pdf (07.10.2014).

Stanisz A., 2007, Przystępny kurs statystyki z zastosowaniem STATISTICA PL na przykładach z medycyny. Tom 3. Analizy wielowymiarowe, StatSoft, Kraków.

Ustawa z 2 lipca 2004 r. o swobodzie działalności gospodarczej, DzU, nr 1731, poz. 1807 ze zm.

Ustawa z 27 lipca 2005 r. Prawo o szkolnictwie wyższym, DzU, nr 164, poz. 1365 ze zm.

ZA5447 Flash Eurobarometer 304 (Employers' Perception of Graduate Employability) Country Specific Questionnaire Poland, https://dbk.gesis.org/dbksearch/download.asp?db=E\&id=18872 (25.09.2014). 